\title{
In vitro resistance of Burkholderia cepacia complex isolates to reactive oxygen species in relation to catalase and superoxide dismutase production
}

\author{
Matthew D. Lefebre ${ }^{1}$ and Miguel A. Valvano ${ }^{1,2}$ \\ Author for correspondence: Miguel A. Valvano. Tel: +1 519661 3996. Fax: +1 5196613499. \\ e-mail:mvalvano@julian.uwo.ca
}

Departments of Microbiology and Immunology, ${ }^{1}$ and Medicine, 2 The University of Western Ontario, London, Ontario, Canada N6A 5C1
The Burkholderia cepacia complex comprises groups of genomovars (genotypically distinct strains with very similar phenotypes) that have emerged as important opportunistic pathogens in cystic fibrosis (CF) patients. The inflammatory response against bacteria in the airways of CF individuals is dominated by polymorphonuclear cells and involves the generation of oxidative stress, which leads to further inflammation and tissue damage. Bacterial catalase, catalase-peroxidase and superoxide dismutase activities may contribute to the survival of $B$. cepacia following exposure to reactive oxygen metabolites generated by host cells in response to infection. In the present study the authors investigated the production of catalase, peroxidase and SOD by isolates belonging to various genomovars of the $B$. cepacia complex. Production of both catalase and SOD was maximal during late stationary phase in almost all isolates examined. Native PAGE identified 13 catalase electrophoretotypes and two SOD electrophoretotypes (corresponding to an Fe-SOD class) in strains belonging to the six genomovars of the $B$. cepacia complex. Seven out of 11 strains displaying high-level survival after $\mathrm{H}_{2} \mathrm{O}_{2}$ treatment in vitro had a bifunctional catalase/peroxidase, and included all the genomovar III strains examined. These isolates represent most of the epidemic isolates that are often associated with the cepacia syndrome. The majority of the isolates from all the genomovars were resistant to extracellular $\mathrm{O}_{2}^{-}$, while resistance to intracellularly generated $\mathrm{O}_{2}^{-}$was highly variable and could not be correlated with the detected levels of SOD activity. Altogether the results suggest that resistance to toxic oxygen metabolites from extracellular sources may be a factor involved in the persistence of $B$. cepacia in the airways of CF individuals.

Keywords: cystic fibrosis, chronic granulomatous disease, oxidative stress, hydrogen peroxide, superoxide anion

\section{INTRODUCTION}

Metabolism of oxygen in aerobic organisms generates toxic reactive species such as superoxide $\left(\mathrm{O}_{2}^{-}\right)$, hydrogen peroxide $\left(\mathrm{H}_{2} \mathrm{O}_{2}\right)$ and hydroxyl radicals $\left(\mathrm{OH}^{-}\right)$(Cline, 1975; Fridovich, 1978; Imlay \& Linn, 1988). Accumulation of these byproducts can cause lethal damage to

Abbreviations: $C F$, cystic fibrosis; $C G D$, chronic granulomatous disease; SOD, superoxide dismutase. cellular proteins, membranes and nucleic acids. Many organisms produce specialized enzymes that neutralize toxic oxygen metabolites (Cline, 1975; Fridovich, 1978; Imlay \& Linn, 1988). Superoxide dismutase (SOD), catalase and catalase-peroxidase are well-known examples of antioxidant enzymes utilized by prokaryotes. SOD detoxifies the $\mathrm{O}_{2}^{-}$anion by a dismutation reaction that generates $\mathrm{H}_{2} \mathrm{O}_{2}$ and $\mathrm{O}_{2}$, while catalase converts toxic $\mathrm{H}_{2} \mathrm{O}_{2}$ into $\mathrm{H}_{2} \mathrm{O}$ and $\mathrm{O}_{2}$ (Fridovich, 1978). In addition to generation of $\mathrm{O}_{2}^{-}$and $\mathrm{H}_{2} \mathrm{O}_{2}$ by the endogenous cellular metabolism, pathogenic micro- 
organisms may encounter extracellular reactive oxygen species from the respiratory burst activity of phagocytic cells (Brown et al., 1995; Cline, 1975). Therefore, bacterial SOD and catalase may play an important role in bacterial survival within the host. SODs of Shigella flexneri (Franzon et al., 1990), Salmonella typhimurium (Fang et al., 1999), Listeria monocytogenes (Welch et al., 1979), Aeromonas salmonicida (Barnes et al., 1996) and Photobacterium damselae (Barnes et al., 1999) have been reported to increase the resistance to killing by oxygen radicals. Catalase activity is thought to protect Staphylococcus aureus (Mandell, 1975), and to a limited extent Shigella flexneri (Franzon et al., 1990), Salmonella typhimurium (Tsolis et al., 1995), Mycobacterium tuberculosis (Manca et al., 1999) and Agrobacterium tumefaciens (Xiu \& Pan, 2000).

Burkholderia cepacia is an aerobic, Gram-negative micro-organism that was originally described as the cause of soft rot in onions (Burkholder, 1950). Over the past 20 years the bacterium has emerged as an important opportunistic pathogen, primarily in chronic granulomatous disease (CGD) and cystic fibrosis (CF) patients (Burkholder, 1950; Govan \& Deretic, 1996; Govan \& Vandamme, 1998). CGD is a rare genetic disorder (Xlinked or autosomal recessive) resulting in a defect in the oxidative killing mechanism of phagocytic cells, thus making them unable to generate the toxic oxygen metabolites normally involved in inactivating engulfed bacteria (Cline, 1975; Speert et al., 1994). These cells still retain their non-oxidative bactericidal activities, mainly through the functions of defensins as well as other bactericidal cationic peptides and proteins (Odell \& Segal, 1991).

CF is an autosomal recessive genetic disorder that affects approximately 1 in 2500 people in the Caucasian population. The disorder compromises the transport of chloride ions through apical epithelial cell membranes and leads to pancreatic insufficiency and abnormally thick mucous secretion in the lungs and other organs (Govan et al., 1996; Govan \& Deretic, 1996; Govan \& Vandamme, 1998). The disease is characterized by bacterial colonization and chronic airway infection and persistent inflammation that progressively compromises the lung function (Bals et al., 1999). Ultimately, chronic inflammation and tissue damage leads to a reduction in the rate of gas exchange at the cellular level and can be fatal. The most common pathogen responsible for the morbidity and mortality in CF patients is Pseudomonas aeruginosa (Koch \& Hoiby, 1993). However, in recent years $B$. cepacia has increasingly been isolated from the airways of CF patients, and is often associated with a rapid decay of the lung function accompanied with a sepsis-like syndrome. This condition, referred to as the 'cepacia syndrome', occurs in roughly $20 \%$ of infected patients (Govan \& Deretic, 1996; Govan \& Vandamme, 1998; Tablan et al., 1985). The severity of B. cepacia infections is amplified by the broad resistance of these micro-organisms to most clinically useful antibiotics, and the fact that they can be effectively transmitted from patient to patient (Govan \& Deretic, 1996; LiPuma et al., 1990). Recent taxonomic studies have shown that strains formerly identified as B. cepacia can be grouped into six genomovars, each containing phenotypically similar yet genotypically distinct organisms (Vandamme et al., 1997). Collectively, these genomovars are referred to as the Burkholderia cepacia complex. Strains belonging to genomovar III have been more commonly linked to fatal infections and constitute most of the epidemic isolates (Vandamme et al., 1997).

Recent investigations in our laboratory have shown that B. cepacia can survive intracellularly in macrophages and amoebae (Marolda et al., 1999; Saini et al., 1999). Survival within professional phagocytes suggests that $B$. cepacia may avoid the bactericidal mechanisms employed by these cells. B. cepacia strains demonstrate resistance to non-oxidative killing pathways, as they are able to survive in the presence of neutrophils from CGD patients while the micro-organisms are killed by neutrophils of normal individuals (Speert et al., 1994). During colonization and infection of the airways in CF patients, there is a pronounced inflammatory response that results in the release of toxic oxygen and toxic nitrogen compounds (Bals et al., 1999). Survival of B. cepacia in a macrophage cell line, in the presence of cell activation and an oxidative burst (Saini et al., 1999), suggests that bacterial resistance to oxidative damage may play a role in the infectivity and persistence of this opportunistic pathogen. B. cepacia isolates are known to produce catalase (Palleroni, 1992) but the presence of SOD has not been investigated. However, it is likely that $B$. cepacia strains produce SOD since this family of enzymes is found in essentially all aerobic forms of life (Weisiger \& Fridovich, 1973).

We hypothesize that SOD and catalase protect B. cepacia from oxidative damage and may contribute to bacterial survival and persistence in infected CF lung and airways. To our knowledge, these enzymes have not been systematically characterized in B. cepacia genomovars. As a step towards examining the role of these enzymes in infection, we have investigated SOD and catalase activities of cell-free cell extracts of isolates representing each genomovar. Native PAGE analysis of cell-free extracts was performed to probe for the presence of multiple isozymes at various growth stages. We also compared the survival rate of $B$. cepacia strains following challenge with both extracellular and intracellular $\mathrm{O}_{2}^{-}$and $\mathrm{H}_{2} \mathrm{O}_{2}$ at concentrations equal or higher than those normally found in vivo, as a consequence of the oxidative burst in phagocytic cells. Our data show that isolates of genomovar III display a uniformly high level of survival in vitro following oxidative stress mediated by extracellular reactive species.

\section{METHODS}

Strains, media and chemicals. Clinical strains of B. cepacia belonging to various genomovars were obtained from the B. cepacia Canadian Repository at the Research Institute for Children's and Women's Health, Vancouver, British Columbia, Canada, and are shown in Table 1. These isolates 
Table 1. Strains used in this study

\begin{tabular}{|c|c|c|c|c|}
\hline Strain & Genomovar* & Source $†$ & RAPD type $\neq$ & Source or reference $\mathbb{S}$ \\
\hline \multicolumn{5}{|l|}{ B. cepacia } \\
\hline FC124 & I & CGD & $\mathrm{X}$ & BCCR \\
\hline CEP509 & I & $\mathrm{CF}$ & 41 & BCCR \\
\hline ATCC 25416 & $\mathrm{I}$ & Onion & 39 & ATCC \\
\hline CEP484 & II & CF & 47 & BCCR \\
\hline C0514 & II & $\mathrm{CF}$ & 5 & BCCR \\
\hline C5274 & II & $\mathrm{CF}$ & 12 & BCCR \\
\hline C7062 & II & $\mathrm{CF}$ & 20 & BCCR \\
\hline ATCC 17616 & II & Soil & 30 & T. Lessie \\
\hline СEP024 & III & $\mathrm{CF}$ & 17 & BCCR \\
\hline CEP511 & III & $\mathrm{CF}$ & 40 & BCCR \\
\hline C1484 & III & $\mathrm{CF}$ & 4 & BCCR \\
\hline C4455 & III & $\mathrm{CF}$ & 6 & BCCR \\
\hline C5424 & III & $\mathrm{CF}$ & 2 & BCCR \\
\hline CEP103 & IV & Clinical, non-CF & $\mathrm{X}$ & BCCR \\
\hline FC473 & IV & CF & $16 c$ & BCCR \\
\hline CEP559 & IV & $\mathrm{CF}$ & 16 & BCCR \\
\hline CEP040 & $\mathrm{V}$ & $\mathrm{CF}$ & 8 & BCCR \\
\hline CEP021 & VI & $\mathrm{CF}$ & 10 & BCCR \\
\hline L6 & VI & $\mathrm{CF}$ & 10 & BCCR \\
\hline \multicolumn{5}{|l|}{ E. coli $\mathrm{K}-12$} \\
\hline UM2 & NA & GC4468, katE katG & NA & Loewen \& Triggs (1984) \\
\hline QC779 & NA & GC4468, sodA sodB & NA & Carlioz \& Touati (1986) \\
\hline
\end{tabular}

* Genomovars II, IV and V of the B. cepacia complex are now designated as B. multivorans (Vandamme et al., 1997), B. stabilis (Vandamme et al., 2000) and B. vietnamiensis (Gillis et al., 1995), respectively. NA, Not applicable.

†CGD, chronic granulomatous disease; CF, cystic fibrosis.

‡RAPD, randomly amplified polymorphic DNA fingerprinting (Mahenthiralingam et al., 1996); X, unassigned profile.

\$BCCR, B. cepacia Canadian Repository; T. Lessie, University of Massachusetts.

were genetically differentiated into the various genomovars by P. Vandamme, Laboratory of Microbiology, University of Gent, Belgium, and by E. Mahenthiralingam, Research Institute for Children's and Women's Health, Vancouver, British Columbia, Canada (Table 1). Genotypic and phenotypic screening indicated that all strains used in this study represented unique isolates rather than clonal variants. Cultures were grown on Luria-Bertani (LB) medium at $37^{\circ} \mathrm{C}$. Preliminary experiments with liquid cultures were done to determine that $\mathrm{OD}_{600}$ values (measured with an Ultrospec II spectrophotometer; Pharmacia) of $0 \cdot 5-0 \cdot 6,0 \cdot 8-0 \cdot 9,1 \cdot 5-2 \cdot 0$ and $2 \cdot 0$ or more corresponded to early exponential phase, late exponential phase, early stationary phase and late stationary phase, respectively. Unless otherwise indicated, chemicals were obtained from Sigma.

Preparation of cell-free cell extracts. Thirty-millilitre cultures were centrifuged at $7000 \mathrm{~g}$ for $10 \mathrm{~min}$. Bacterial pellets were washed with ice-cold $0.05 \mathrm{M}$ sodium phosphate buffer $(\mathrm{pH}$ $7 \cdot 0$ ) and finally resuspended in $3 \mathrm{ml} 0.05 \mathrm{M}$ sodium phosphate buffer, supplemented with $0 \cdot 1 \%$ dithiothreitol and stored on ice. Cells were lysed by sonication with a sonifier cell disrupter model W-350 (Branson Ultrasonics) for a total of $3 \mathrm{~min}$ in three $60 \mathrm{~s}$ pulses on ice. Lysates were centrifuged at $12000 \mathrm{~g}$ for 5 min to sediment cellular debris and unlysed cells.
Supernatants were stored at $-20^{\circ} \mathrm{C}$ in $50 \%(\mathrm{v} / \mathrm{v})$ glycerol. Under these conditions both SOD and catalase activities could be preserved for several months. The protein concentration of cell-free extracts was measured according to the Bio-Rad protein assay using bovine serum albumin as a standard.

Enzymic activity assays. The specific catalase activity was determined spectrophotometrically by following the disappearance of $\mathrm{H}_{2} \mathrm{O}_{2}$ over time at $240 \mathrm{~nm}$, upon the addition of cell-free extract (Katsuwon \& Anderson, 1992). One unit of catalase will decompose $1 \mu \mathrm{mol}_{2} \mathrm{O}_{2}(\mathrm{mg} \text { protein })^{-1} \mathrm{~min}^{-1}$ at $25^{\circ} \mathrm{C}$ (Katsuwon \& Anderson, 1989). The specific peroxidase activity was determined spectrophotometrically by following the oxidation of $o$-dianisidine at $460 \mathrm{~nm}$ in a reaction buffer containing $50 \mathrm{mM}$ potassium phosphate and $1 \mathrm{mM} \mathrm{H}_{2} \mathrm{O}_{2}$ upon the addition of cell-free extract. One unit of peroxidase activity equals $1 \mu \mathrm{mol} \mathrm{H}_{2} \mathrm{O}_{2}$ reduced $\min ^{-1}$, with $\varepsilon_{\mathrm{M}}=$ $11.3 \times 10^{4} \mathrm{M}^{-1} \mathrm{~cm}^{-1}$ (Schnell \& Steinman, 1995). The specific SOD activity was determined spectrophotometrically by measuring the inhibition of the initial rate of auto-oxidation of 6-hydroxydopamine at $490 \mathrm{~nm}$ following the addition of cell-free extract (Heikkila \& Cabbat, 1976). A standard curve using known units of SOD activity was generated in order to determine the units of activity in each sample. One unit of SOD activity corresponded to $50 \%$ inhibition of the initial 
rate. Bovine liver catalase and both iron- and manganesecontaining SOD enzymes (Fe-SOD and Mn-SOD) from Escherichia coli were used as positive controls in the respective assays.

Native PAGE for identification of catalase, peroxidase and SOD. We used native PAGE to identify bands of catalase (Katsuwon \& Anderson, 1992). Lanes were loaded with 10-20 $\mu \mathrm{g}$ total protein and the electrophoresis was carried out using $10 \%$ Novex gels. Gels were washed with distilled water for $30 \mathrm{~min}$ to remove any traces of running buffer. To identify bands of catalase activity the gel was soaked in $200 \mathrm{ml}$ of a $3 \mathrm{mM}$ solution of $\mathrm{H}_{2} \mathrm{O}_{2}$ for $10 \mathrm{~min}$ and then rinsed in distilled $\mathrm{H}_{2} \mathrm{O}$. Following the addition of a $1 \%$ potassium ferricyanide $/ 1 \%$ ferric chloride $(\mathrm{w} / \mathrm{v})$ solution for $10 \mathrm{~min}$ in darkness, the gel stained dark blue except at sites showing catalase activity, which appeared clear. Bovine liver catalase was used as a positive control. Bands of peroxidase activity were visualized using the method described by Wayne \& Diaz (1986). Briefly, following electrophoresis as described above, gels were washed for $30 \mathrm{~min}$ in phosphate-buffered saline (PBS). To identify bands of peroxidase activity the gels were soaked in a $200 \mathrm{ml}$ PBS solution containing $1.0 \mathrm{mM} \mathrm{H}_{2} \mathrm{O}_{2}$ and $2 \cdot 0 \mathrm{mM} \mathrm{3,3}$-diaminobenzidine tetrahydrochloride for $30 \mathrm{~min}$. Sites of peroxidase activity appeared brown on a clear background. Type II horseradish peroxidase was used as a positive control. In order to determine whether bands showing peroxidase activity were due to bifunctional catalase-peroxidase enzymes, gels were washed in distilled water and counter-stained for catalase activity as described above. Heat inactivation was performed by incubating samples at $65^{\circ} \mathrm{C}$ for 1 min immediately prior to loading (Wayne \& Diaz, 1986). Chemical inactivation of catalase activity was performed by incubating extracts with 3-amino-1,2,4-triazole for $20 \mathrm{~min}$. Bands of SOD activity were identified by the native PAGE method described by Beauchamp \& Fridovich (1971). Lanes were routinely loaded with $20-40 \mu \mathrm{g}$ total protein. After electrophoresis, under the conditions as described above, gels were washed for $30 \mathrm{~min}$ in distilled water, and incubated with shaking in the dark for $30 \mathrm{~min}$ in a solution of $250 \mu \mathrm{M}$ nitro blue tetrazolium (NBT) dissolved in $200 \mathrm{ml}$ distilled water. Gels were then incubated in a developing solution containing $50 \mathrm{mM}$ potassium phosphate, $\mathrm{pH} 7 \cdot 8,1 \mathrm{mM}$ EDTA, $\mathrm{pH} 8 \cdot 0$, $20 \mathrm{mM} N, N, N^{\prime}, N^{\prime}$-tetramethylethylenediamine (Bio-Rad) and $30 \mu \mathrm{M}$ riboflavin in the dark with shaking for $20 \mathrm{~min}$. Bands of SOD activity were visualized by exposing the gels to light for $10 \mathrm{~min}$ or until sufficient contrast with the background developed. Sites with SOD activity appeared clear on a purple background. Both Fe-SOD and Mn-SOD purified from E. coli were used as positive controls in this assay.

In vitro protection assays. The level of protection against $\mathrm{H}_{2} \mathrm{O}_{2}$ exposure in the strains used in this study was measured as described by Katsuwon \& Anderson (1989). Briefly, cultures of $B$. cepacia were grown with shaking at $37^{\circ} \mathrm{C}$ in $\mathrm{LB}$ broth until late stationary phase. Samples containing $1 \times 10^{8}$ cells $\mathrm{ml}^{-1}$ of each strain were treated with various $\mathrm{H}_{2} \mathrm{O}_{2}$ concentrations and incubated with shaking at $25^{\circ} \mathrm{C}$ for $30 \mathrm{~min}$. Control samples received $\mathrm{H}_{2} \mathrm{O}$ in place of $\mathrm{H}_{2} \mathrm{O}_{2}$ treatment. Appropriate serial dilutions were plated in triplicate on LB agar plates. Colonies were counted after $48 \mathrm{~h}$ incubation and percentage survival calculated by comparison with colony counts obtained from untreated samples. The level of protection of strains to extracellular $\mathrm{O}_{2}^{-}$exposure was measured as described elsewhere (Schnell \& Steinman, 1995) with some modifications. Late stationary phase culture samples containing $1 \times 10^{8}$ cells $\mathrm{ml}^{-1}$ were incubated with shaking at $37^{\circ} \mathrm{C}$ in a mixture containing $250 \mu \mathrm{M}$ xanthine $(\mathrm{X})$ and $0 \cdot 14$ units of xanthine oxidase (XO); $100 \mathrm{U}$ catalase $\mathrm{ml}^{-1}$ was added to each sample prior to addition of $\mathrm{XO}$ to protect cells from the toxicity of any $\mathrm{H}_{2} \mathrm{O}_{2}$ produced as a consequence of SOD activity. Aliquots were removed at 0, 30, 60 and $120 \mathrm{~min}$ and serially diluted in $200 \mathrm{mM}$ phosphate buffer, $\mathrm{pH} 7 \cdot 4$. Time 0 aliquots were removed before addition of the $\mathrm{O}_{2}^{-}$generating components. Appropriate dilutions were plated in triplicate on LB agar plates, incubated for $24-48 \mathrm{~h}$ at $37^{\circ} \mathrm{C}$ and the colonies counted. Percentage survival was determined using the following equation: \% Survival $=$ (No. of colonies, treated sample/No. of colonies at time 0$) \times 100$. Survival after intracellular $\mathrm{O}_{2}^{-}$exposure was measured using the liquid assay. The liquid assay was performed as described by Membrillo-Hernandez et al. (1999) with some modifications. Cultures of $B$. cepacia strains were grown to late stationary phase. Samples containing $1 \times 10^{8}$ cells $\mathrm{ml}^{-1}$ were incubated with shaking at $37^{\circ} \mathrm{C}$ in a mixture containing $0,2.5,5$ or $10 \mathrm{mM}$ paraquat. Aliquots were removed after $45 \mathrm{~min}$, serially diluted and plated in triplicate on LB agar plates. Following incubation at $37^{\circ} \mathrm{C}$ for $24-48 \mathrm{~h}$, colonies were counted and percentage survival was calculated using the equation described above.

Statistical analysis. Data were analysed using the Fisher least significant difference (LSD) method, using 95\% confidence intervals.

\section{RESULTS}

\section{Catalase production by strains of the $B$. cepacia complex}

We examined catalase production in a set of 19 isolates representing the six known genomovars of the $B$. cepacia complex (Table 1). These included clinical isolates as well as two isolates from environmental sources. The catalase activity in cell-free extracts was determined spectrophotometrically by following the degradation of $\mathrm{H}_{2} \mathrm{O}_{2}$ at $240 \mathrm{~nm}$. An extract from the E. coli $\mathrm{K}-12$ catalase-deficient mutant strain UM2, lacking functional $k a t E$ and $k a t G$ genes, was used as a negative control for the assay, while bovine catalase served as a positive control. In general, there was a wide range in the amount of catalase activity produced by individual isolates of genomovars I, II and III (Table 2). This variability was not due to experimental error since similar enzyme units for a given isolate were detected in repeated experiments. No significant differences were observed in the average catalase production among the various genomovar isolates. However, the catalase activity significantly increased in extracts prepared from isolates grown to late stationary phase, ranging from fivefold to several thousandfold with respect to the levels measured in extracts obtained from cells in the exponential phase.

Native PAGE analysis of cell-free extracts, derived from cultures at various growth stages, yielded 13 distinct catalase electrophoretotypes (Fig. 1a). Extracts with enzymic activities below $10^{-6}$ units (mg protein $)^{-1}$ (Table 2) did not produce detectable bands under the staining conditions used. It should be noted that the band designation simply reflects the mobility of the enzyme in the gel but does not imply that the enzymes with similar mobility are indeed identical (see below). 
Table 2. Catalase and peroxidase activities in B. cepacia strains according to growth phase

See Methods for the $\mathrm{OD}_{600}$ ranges defining the growth stages. Specific activity of the enzymes is indicated as units per mg protein.

\begin{tabular}{|c|c|c|c|c|c|}
\hline \multirow[t]{2}{*}{ Strain } & \multirow[t]{2}{*}{ Genomovar } & \multicolumn{2}{|c|}{ Early exponential } & \multicolumn{2}{|c|}{ Late stationary } \\
\hline & & $\begin{array}{l}\text { Catalase } \\
\text { activity }\end{array}$ & $\begin{array}{c}\text { Peroxidase } \\
\text { activity }\end{array}$ & $\begin{array}{c}\text { Catalase } \\
\text { activity }\end{array}$ & $\begin{array}{c}\text { Peroxidase } \\
\text { activity }\end{array}$ \\
\hline FC124 & I & $1 \cdot 6$ & - & $6 \cdot 6$ & - \\
\hline CEP509 & I & $1 \cdot 5$ & $6.5 \times 10^{-4}$ & $6 \cdot 4$ & $3 \times 10^{-3}$ \\
\hline ATCC 25416 & I & $6 \times 10^{-7}$ & - & 0.5 & - \\
\hline CEP484 & II & $0 \cdot 1$ & - & $1 \cdot 3$ & - \\
\hline C0514 & II & $0 \cdot 2$ & - & $1 \cdot 1$ & - \\
\hline C5274 & II & $2 \cdot 3 \times 10^{-7}$ & - & $0 \cdot 4$ & - \\
\hline C7062 & II & $3 \cdot 2 \times 10^{-7}$ & - & $11 \cdot 9$ & - \\
\hline ATCC 17616 & II & $2 \times 10^{-8}$ & - & $0 \cdot 4$ & - \\
\hline СЕР024 & III & $7 \cdot 2 \times 10^{-2}$ & $<10^{-8}$ & $9 \cdot 4$ & $5 \times 10^{-3}$ \\
\hline CEP511 & III & $0 \cdot 2$ & $1 \times 10^{-4}$ & $1 \cdot 4$ & $6.5 \times 10^{-6}$ \\
\hline C1484 & III & $0 \cdot 1$ & $8 \times 10^{-5}$ & 0.7 & $5 \times 10^{-4}$ \\
\hline C4455 & III & $0 \cdot 6$ & $2.7 \times 10^{-3}$ & $3 \cdot 9$ & $3 \times 10^{-3}$ \\
\hline C5424 & III & $2 \cdot 3$ & $9 \times 10^{-3}$ & 29 & $1 \times 10^{-2}$ \\
\hline CEP103 & IV & $4 \times 10^{-8}$ & - & $0 \cdot 1$ & - \\
\hline FC473 & IV & $8 \times 10^{-8}$ & $<10^{-8}$ & $1 \cdot 5$ & $1 \cdot 8 \times 10^{-3}$ \\
\hline CEP559 & IV & $4 \times 10^{-8}$ & $<10^{-8}$ & $0 \cdot 9$ & $2 \cdot 0 \times 10^{-3}$ \\
\hline CEP040 & $\mathrm{V}$ & $2 \times 10^{-8}$ & - & $0 \cdot 4$ & - \\
\hline СЕР021 & VI & $0 \cdot 9$ & $1.5 \times 10^{-4}$ & $2 \cdot 3$ & $1.6 \times 10^{-4}$ \\
\hline L6 & VI & $0 \cdot 2$ & $<10^{-8}$ & 12 & $2 \cdot 3 \times 10^{-3}$ \\
\hline UM2 & E. coli & $\mathrm{ND}$ & $\mathrm{ND}$ & $<10^{-8}$ & $<10^{-8}$ \\
\hline
\end{tabular}

Likewise, enzymes with different gel mobility could have small variations in amino acid composition that may affect dramatically the electrophoretic migration into the gel or may correspond to protein aggregates that cannot be resolved by native PAGE. The bands detected in each strain at the various growth stages are summarized in Table 3 using the band designations from Fig. 1(a). Based on the analysis of this limited set of strains, it appeared that some bands were consistently associated with particular genomovars. Band 13 was present in the genomovar V strain CEP040, the genomovar VI strain L6, and all genomovar III strains, except for strain CEP024. Band 11 appeared in all strains belonging to genomovars II and VI.

Catalases can exist as monofunctional or bifunctional enzymes. Bifunctional catalases usually carry an additional peroxidase activity. Thus, peroxidase activity in cell-free lysates was determined spectrophotometrically by following the oxidation of $o$-dianisidine at $460 \mathrm{~nm}$. In this case, type II horseradish peroxidase served as a positive control while the E. coli $\mathrm{K}-12$ catalase-deficient mutant strain UM2 was used as a negative control for the assay. Extracts from all isolates belonging to genomovars III, IV and VI, but only one from a genomovar I strain, were positive for peroxidase activity (Table 2). Strains belonging to genomovar II showed no detectable peroxidase activity. As with catalase activity, the level of peroxidase activity measured was maximal during stationary phase for all strains except for CEP511. To determine whether the detected peroxidase and catalase activities were associated with the same enzyme we conducted native PAGE analysis combining the specific staining for peroxidase activity with that for catalase (Fig. 1c). In all peroxidase-positive strains, the band with peroxidase activity co-migrated with the band of catalase activity (Fig. 1c, lane 1). No bands of peroxidase activity, independent of catalase activity, were detected in any of the extracts investigated. These observations confirm the presence of bifunctional catalase/peroxidase enzymes. Furthermore, all bands showing both enzymic activities disappeared when samples were incubated at $65^{\circ} \mathrm{C}$ for $1 \mathrm{~min}$ prior to loading the gel, while bands corresponding to monofunctional enzymes were heat-resistant (Fig. 1c, Table 2 ). The heat sensitivity of the bifunctional enzymes observed in the native PAGE analysis was corroborated by similar observations on overall levels of enzyme activity in heat-treated cell-free extracts (Table 3 and data not shown). Heat sensitivity is a typical feature 

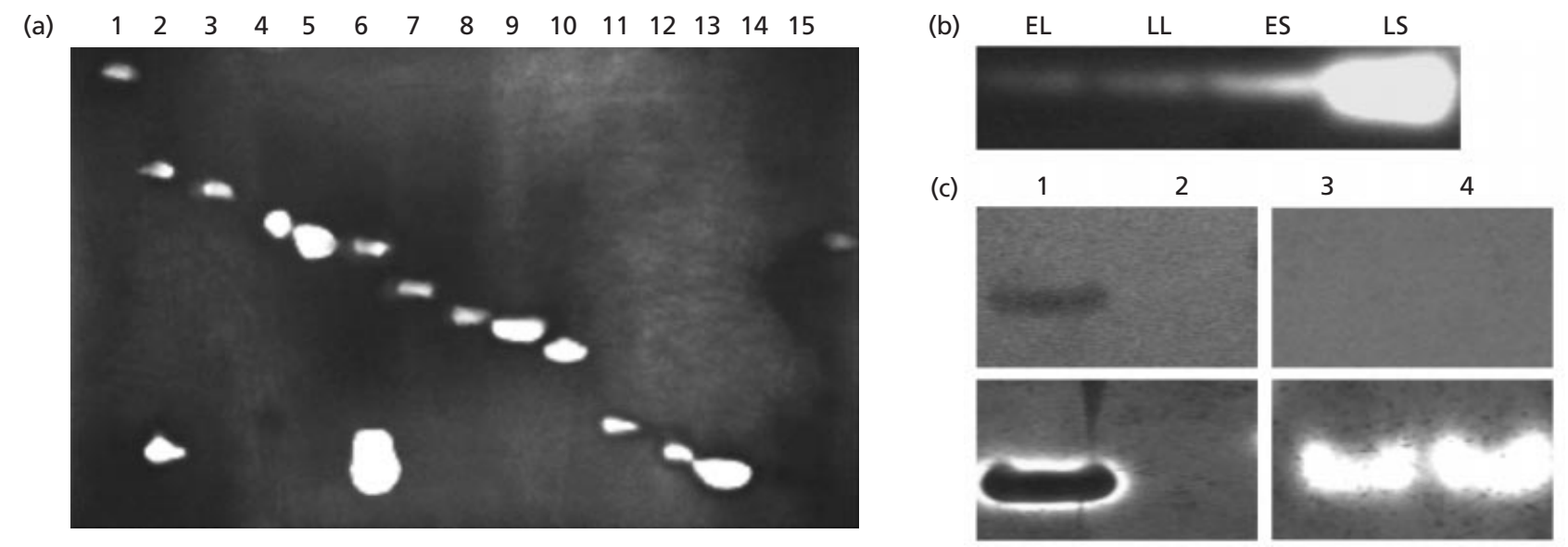

Fig. 1. Detection of catalase activities in cell-free cell lysates from strains belonging to genomovars I through $\mathrm{VI}$ of the $B$. cepacia complex. Extracts were analysed by native PAGE followed by staining with potassium ferricyanide. (a) Identification of the 13 catalase electrophoretotypes (lanes 1-13) present in strains belonging to genomovars I-VI of the $B$. cepacia complex. Each lane was loaded with $10-20 \mu \mathrm{g}$ total protein in order to visualize the relevant eletrophoretotypes from the following strains (growth stage indicated in parentheses; see below): lane 1, ATCC 25416 (LS); 2, CEP024 (ES); 3, C0514 (LL); 4, C7062 (ES); 5, CEP484 (ES); 6, C4455 (LS); 7, CEP484 (LL); 8, FC473 (LS); 9 , FC124 (LS); 10, CEP509 (LS); 11, CEP021 (LS); 12, CEP024 (LS); 13, CEP511 (LS). Lane 14, extract from E. coli UM2 (katF katG) used as a negative control. Lane 15, bovine catalase (1 unit) used as a positive control. Additional bands in lanes 2 and 6 , corresponding to electrophoretotypes 12 and 13 respectively, are present in the specified samples used. The apparent doublet visible in lane 6 is an artifact of the excess protein loaded to visualize the much weaker band 6 . Not all bands associated with the indicated extracts (Table 3) are visible at the protein concentrations loaded in this gel. (b) Stationaryphase induction of catalase activity observed in B. cepacia strain C1484. The electrophoretotype corresponds to band 13. EL, early exponential phase; LL, late exponential phase; ES, early stationary phase; LS, late stationary phase. (c) Identification of bifunctional catalase-peroxidase enzymes in strains belonging to the $B$. cepacia complex. Top panel, native PAGE followed by staining with 3,3'-diaminobenzidine tetrahydrochloride for peroxidase activity. Bottom panel, counterstaining using catalase-specific potassium ferricyanide stain. Lanes: 1, C4455; 2, heat-treated C4455; 3, CEP484; 4, heat-treated CEP484.

of bifunctional catalase/peroxidases; monofunctional catalases are typically heat resistant (Wayne \& Diaz, 1986). Detection of both catalase and peroxidase activities in association with specific electrophoretotypes also allowed us to distinguish between the monofunctional catalase present in genomovar II strains and the bifunctional catalase/peroxidase present in genomovar VI strains, both of which had apparently the same electrophoretotype (band 11). Also, the band 13 present in genomovar III strains corresponded to a bifunctional catalase/peroxidase while the band with similar mobility found in the genomovar $\mathrm{V}$ strain CEP040 corresponded to a monofunctional catalase (Table 3). The results indicate that these bands, although identical in gel mobility, clearly corresponded to two different classes of catalases. Furthermore, in the case of the genomovar I strain CEP509, band 1 corresponded to a monofunctional catalase while the bifunctional catalase/peroxidase activity was associated with band 10 . Bands 2 and 6, seen in the genomovar III strains CEP024 and C4455, respectively (Table 3), also disappeared after heating, and it is quite possible that these bands corresponded to aggregates of bands 12 and 13 . In the genomovar II strains, we observed that the slowmigrating bands 3, 4 and 5 appeared and/or disappeared from the same strain at different growth stages (Table 3). All of these bands were absent in heat-treated extracts, while the corresponding lower band 11 was always detected. Since the genomovar II strains do not produce a detectable heat-sensitive bifunctional catalase/peroxidase we concluded that the slow-migrating bands also corresponded to protein aggregates of a single monofunctional catalase represented by band 11 . Therefore we propose that of the 13 electrophoretotypes observed, only bands $1,7,8,9,10,11,12$ and 13 represent distinct catalase activities while the remaining bands $(2,3,4,5,6)$ correspond to multimeric aggregates.

\section{SOD production by strains of the $B$. cepacia complex}

Cell-free extracts were also used to determine the specific SOD activity by measuring the inhibition of the initial rate of auto-oxidation of 6-hydroxydopamine at $490 \mathrm{~nm}$. This assay was chosen because it does not suffer any interference from other components in the crude cell-free lysates (Bannister \& Calabrese, 1987). The E. coli K-12 $\operatorname{sodA} \operatorname{sodB}$ mutant QC779 was used as a negative control for the assay. Units of SOD activity were calculated by generating a standard curve with FeSOD from E. coli as a control, where 1 unit represented $50 \%$ inhibition of auto-oxidation of the substrate. Table 4 shows the SOD activities for each strain at the early exponential and late stationary growth stages. As with catalase activities, the level of SOD activity measured 
Table 3. Distribution of catalase electrophoretotypes at various growth stages

Distribution of electrophoretotypes among the isolates of the B. cepacia complex, using the same band designations as shown in Fig. 1(a). Numbers in bold denote bands displaying a bifunctional catalase/peroxidase activity (which also disappeared with heat treatment). Numbers in italics denote bands that correspond to protein aggregates as explained in the text. $\mathrm{N} / \mathrm{B}$ indicates that a band was not detectable. The $\mathrm{OD}_{600}$ ranges defining the various growth stages are indicated in Methods.

\begin{tabular}{|lccccc|}
\hline Strain & Genomovar & $\begin{array}{c}\text { Early } \\
\text { exponential }\end{array}$ & $\begin{array}{c}\text { Late } \\
\text { exponential }\end{array}$ & $\begin{array}{c}\text { Early } \\
\text { stationary }\end{array}$ & $\begin{array}{c}\text { Late } \\
\text { stationary }\end{array}$ \\
\hline FC124 & I & 9 & 9 & 9 & 9 \\
CEP509 & I & $1, \mathbf{1 0}$ & $1, \mathbf{1 0}$ & $1, \mathbf{1 0}$ & $1, \mathbf{1 0}$ \\
ATCC 25416 & I & N/B & N/B & 1 & 1 \\
CEP484 & II & 7 & 7 & 5,11 & 5,11 \\
C0514 & II & 3,11 & 3 & N/B & 3,11 \\
C5274 & II & N/B & N/B & N/B & 7,11 \\
C7062 & II & N/B & N/B & 4,11 & 5,11 \\
ATCC 17616 & II & N/B & 11 & 5,11 & 5,11 \\
CEP024 & III & $\mathbf{1 2}$ & $\mathbf{1 2}$ & $2, \mathbf{1 2}$ & $\mathbf{1 2}$ \\
CEP511 & III & $\mathbf{1 3}$ & 13 & N/B & $\mathbf{1 3}$ \\
C1484 & III & $\mathbf{1 3}$ & $\mathbf{1 3}$ & $\mathbf{1 3}$ & $\mathbf{1 3}$ \\
C4455 & III & $\mathbf{1 3}$ & $\mathbf{1 3}$ & $\mathbf{1 3}$ & $6, \mathbf{1 3}$ \\
C5424 & III & $\mathbf{1 3}$ & $\mathbf{1 3}$ & $\mathbf{1 3}$ & $\mathbf{1 3}$ \\
CEP103 & IV & N/B & N/B & $\mathbf{8}$ & $\mathbf{8}$ \\
FC473 & IV & N/B & $\mathbf{8}$ & $\mathbf{8}$ & $\mathbf{8}$ \\
CEP559 & IV & N/B & $\mathbf{8}$ & $\mathbf{8}$ & $\mathbf{8}$ \\
CEP040 & V & N/B & N/B & 13 & 13 \\
CEP021 & VI & $\mathbf{1 1}$ & $\mathbf{1 1}$ & $\mathbf{1 1}$ & $\mathbf{1 1}$ \\
L6 & VI & $\mathbf{1 1}$ & $\mathbf{1 1}$ & $\mathbf{1 1 , 1 3}$ & $\mathbf{1 1 , 1 3}$ \\
\hline
\end{tabular}

increased dramatically in the extracts from cultures at stationary phase. Likewise, genomovar III strains also appeared to possess, on average, higher levels of SOD activity than the strains belonging to the other genomovars (Table 4). However, following statistical analysis, the levels of SOD activity observed for strains from the various genomovars were not significantly different.

Native PAGE analysis of cell-free cell extracts identified two distinct SOD electrophoretotypes (Fig. 2a, b). In all cases, the SOD activity was maximal at the late stationary stage of growth based on band intensity (Fig. 2c). While the fastest-migrating species (band 2, Fig. 2a) was present in all the strains, the other species (band 1, Fig. 2a) was not equally distributed (Table 4). Based on the banding pattern generated by each strain at the various growth stages, we concluded that the majority of SOD activity was associated with band 2 in all strains except for CEP511 and FC124, which produced a more intense band 1 . In all cases, the more intense band was detected at all stages of growth while the other band became apparent only during stationary phase (Table 4). More thorough analysis identified an additional band of activity that was very weak and only became clearly visible when $75 \mu \mathrm{g}$ total protein was loaded in the gels. This band was exclusively present in the extracts that contained an intense band 2, but disappeared when the extracts were incubated at $65^{\circ} \mathrm{C}$ for $1 \mathrm{~min}$. Also, this band of activity was not detected in extracts loaded on gels with $10 \%$ acrylamide. Taking into consideration the association of this band with band 2, its heatsensitive nature (SOD enzymes are typically heat stable), its slow migration and comparatively low amount, we conclude that this band possibly corresponds to a multimeric enzyme aggregate of band 2 .

Depending on the metal co-factor, SOD enzymes can be distinguished as Fe-SOD, Mn-SOD and $\mathrm{Cu} / \mathrm{Zn}-\mathrm{SOD}$. These SOD forms can be separated on the basis of their sensitivities to various inhibitors. Fe-SOD enzymes are inhibited by exposure to $\mathrm{H}_{2} \mathrm{O}_{2}$ while the $\mathrm{Cu} / \mathrm{Zn}$ form is inhibited by potassium cyanide. Mn-SOD enzymes are usually resistant to both inhibitors. Following treatment with the selected inhibitors, bands of activity on native gels are retained or lost depending on the type of SOD present. Initial attempts to classify the SOD enzymes from B. cepacia proved unsuccessful. This was probably due to interactions of the specific inhibitors with other components of the cell-free lysates used for these studies. This was clearly evident with the addition of $\mathrm{H}_{2} \mathrm{O}_{2}$ to the samples, as the catalase activity rapidly produced bubbling, a sign of $\mathrm{H}_{2} \mathrm{O}_{2}$ degradation. To eliminate 
Table 4. SOD activity in B. cepacia strains according to growth phase

\begin{tabular}{|c|c|c|c|c|}
\hline \multirow[t]{2}{*}{ Strain } & \multirow[t]{2}{*}{ Genomovar } & \multirow{2}{*}{$\begin{array}{c}\text { Band } \\
\text { profile* }\end{array}$} & \multicolumn{2}{|c|}{ SOD activity $\dagger$} \\
\hline & & & $\begin{array}{c}\text { Early } \\
\text { exponential } \neq\end{array}$ & $\begin{array}{c}\text { Late } \\
\text { stationary } \$\end{array}$ \\
\hline CEP509 & I & 2 & $43 \cdot 1$ & $74 \cdot 5$ \\
\hline ATCC 25416 & I & 2 & $30 \cdot 6$ & $45 \cdot 9$ \\
\hline FC124 & I & 1,2 & $52 \cdot 6$ & $85 \cdot 5$ \\
\hline C5274 & II & 2 & $24 \cdot 2$ & $69 \cdot 1$ \\
\hline C7062 & II & 2 & $22 \cdot 3$ & $168 \cdot 2$ \\
\hline C0514 & II & 2 & 35 & $54 \cdot 7$ \\
\hline CEP484 & II & 2 & $22 \cdot 3$ & $209 \cdot 5$ \\
\hline ATCC17616 & II & 2,1 & $31 \cdot 9$ & 91 \\
\hline C4455 & III & 2,1 & $35 \cdot 2$ & 100 \\
\hline СЕР024 & III & 2 & $17 \cdot 3$ & 139 \\
\hline CEP511 & III & 1,2 & $39 \cdot 5$ & 88 \\
\hline C1484 & III & 2 & 64 & 167 \\
\hline C5424 & III & 2,1 & 81 & 191 \\
\hline FC473 & IV & 2,1 & $41 \cdot 2$ & $91 \cdot 3$ \\
\hline CEP559 & IV & 2,1 & 27 & $91 \cdot 8$ \\
\hline CEP103 & IV & 2,1 & $37 \cdot 7$ & $78 \cdot 6$ \\
\hline CEP40 & V & 2 & 51 & 127 \\
\hline СЕР021 & VI & 2 & $40 \cdot 4$ & 67 \\
\hline L6 & VI & 2 & 40 & 147 \\
\hline QC779 & E. coli & ND & ND & 6 \\
\hline
\end{tabular}

*Bold numbers indicate the SOD electrophoretotype that appeared with the highest intensity in native PAGE gels; ND, not determined.

† SOD activity was measured spectrophotometrically as described in Methods. Specific activity is indicated as units per $\mathrm{mg}$ protein.

$\ddagger$ Early exponential phase cells $\left(\mathrm{OD}_{600} 0 \cdot 5-0 \cdot 6\right)$.

SLate stationary phase cells $\left(\mathrm{OD}_{600}>2 \cdot 0\right)$.

catalase activity from our samples we took advantage of the information gathered regarding the types of catalase present in each of the isolates. Bifunctional catalase peroxidase enzymes were inactivated by incubation at $65^{\circ} \mathrm{C}$ for 1 min while monofunctional enzymes were inactivated by treatment with 3-amino-1,2,4-triazole for 20 min (Marcinkeviciene et al., 1995). Following catalase inactivation, samples were treated with $25 \mathrm{mM}$ $\mathrm{H}_{2} \mathrm{O}_{2}$ for 20 min prior to loading into the gel, and then stained for SOD activity as described above. Control experiments indicated that neither heat treatment nor the addition of 3-amino-1,2,4-triazole affected the detection of SOD activity by native PAGE (data not shown). Addition of $\mathrm{H}_{2} \mathrm{O}_{2}$ following heat treatment and/or 3-amino-1,2,4-triazole exposure resulted in the inactivation of all SOD activity in the extracts from all the strains (Fig. 3, lanes 5-8, and data not shown). The inhibition with $\mathrm{H}_{2} \mathrm{O}_{2}$ was specific for Fe-SOD since the activity of an Mn-SOD from E. coli used as a control was not affected by the inhibitor (Fig. 3, lanes 1 and 2) while the activity of an Fe-SOD from E. coli was abolished (Fig. 3, lanes 3 and 4). Therefore, we concluded that the SOD form in all the B. cepacia strains examined in this study under our experimental conditions corresponded to an Fe-SOD class.

\section{Bacterial susceptibility to killing by $\mathrm{H}_{2} \mathrm{O}_{2}$ and superoxide anion}

To ascertain whether the differential production of SOD and catalase activities by individual isolates has any biological significance, we evaluated the susceptibility of our isolates to both $\mathrm{H}_{2} \mathrm{O}_{2}$ and $\mathrm{O}_{2}^{-}$exposure. The results were expressed as percentage survival relative to the same bacterial inoculum in the absence of the reactive oxygen species. The level of resistance to killing by $\mathrm{H}_{2} \mathrm{O}_{2}$ was assessed by exposing bacterial cells to incremental concentrations of $\mathrm{H}_{2} \mathrm{O}_{2}$ ranging from $2.5 \mathrm{mM}$ to $10 \mathrm{mM}$, as indicated in Methods. We first conducted pilot experiments with selected strains of each genomovar to determine the survival of cultures grown to exponential and stationary phase following $\mathrm{H}_{2} \mathrm{O}_{2}$ exposure. In all cases, survival increased dramatically in stationary-phase cultures (data not shown), in agreement with the data showing an increased enzyme activity at this growth stage (Table 2, Fig. 1b). There- 
(a)

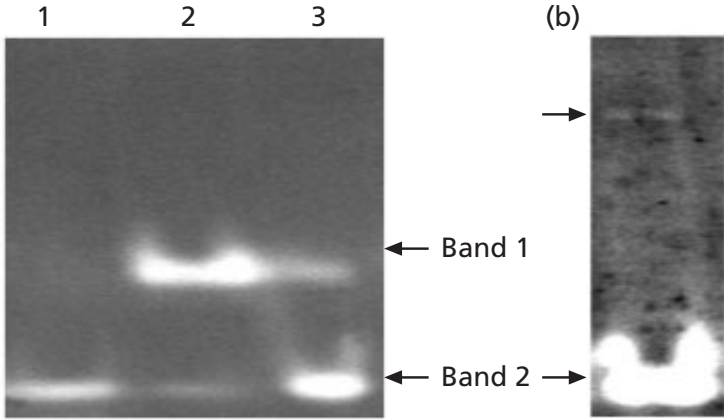

(c)

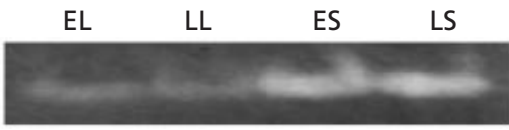

Fig. 2. Detection of SOD activities in cell-free cell lysates of $B$. cepacia complex strains using native PAGE followed by staining as described in Methods. (a) Identification of two SOD electrophoretotypes present in strains belonging to genomovars I to VI. Band 1 represents electrophoretotype 1; band 2 represents electrophoretotype 2 . Each lane was loaded with $40 \mu \mathrm{g}$ total protein from extracts generated from late stationary cultures. Lanes: 1 , L6; 2, FC124; 3, C5424. (b) Lane overloaded with $75 \mu \mathrm{g}$ total protein from L6 to visualize a weak band of SOD activity thought to correspond to an aggregate of band 2 (arrow). (c) Stationary-phase induction of SOD activity observed in B. cepacia strain C1484. Each lane was loaded with $20 \mu \mathrm{g}$ total protein. Visible electrophoretotype corresponds to band 3. EL, early exponential phase; LL, late exponential phase; ES, early stationary phase; LS, late stationary phase, as defined in Methods.

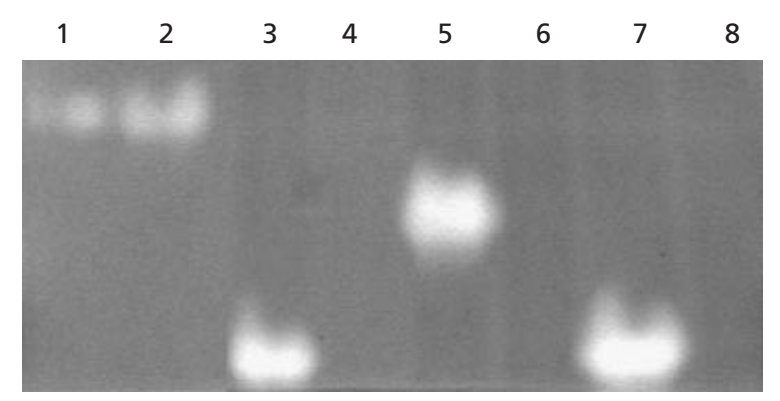

Fig. 3. Determination of the SOD class. Cell-free extracts were pre-treated by heating at $65^{\circ} \mathrm{C}$ for $1 \mathrm{~min}$ to inactivate bifunctional catalase/peroxidase activity and/or with $20 \mathrm{mM} \mathrm{3-}$ amino-1,2,4-triazole for $20 \mathrm{~min}$ to inactivate monofunctional catalase activity. Subsequently extracts were treated with $25 \mathrm{mM} \mathrm{H}_{2} \mathrm{O}_{2}$ for $20 \mathrm{~min}$ at room temperature to inactivate $\mathrm{Fe}-$ SOD. Odd-numbered and even-numbered lanes were loaded with untreated and treated extracts, respectively. Lanes: 1 and 2, E. coli Mn-SOD; 3 and 4, E. coli Fe-SOD; 5 and 6, B. cepacia FC124; 7 and 8, B. cepacia C5424.

fore, the remaining experiments were conducted using cultures in stationary phase. Strains belonging to genomovar III showed a uniformly high level of resistance to $\mathrm{H}_{2} \mathrm{O}_{2}$ at all concentrations tested (Fig. 4). Survival of one strain in this group, C5424, was assayed at higher $\mathrm{H}_{2} \mathrm{O}_{2}$ concentrations, showing that it was capable of surviving in up to $100 \mathrm{mM} \mathrm{H}_{2} \mathrm{O}_{2}$ (data not shown). In contrast, the susceptibility of strains from the other genomovars showed much more variation among individual isolates, although some strains, notably the two genomovar VI isolates, also displayed high levels of resistance comparable with that observed with genomovar III isolates (Fig. 4). The survival rate could not be directly correlated with levels of catalase activity alone. However, 7 out of 11 strains showing the highest survival rates (above $25 \%$ with respect to the initial inoculum) at the highest $\mathrm{H}_{2} \mathrm{O}_{2}$ concentrations were those producing a bifunctional catalase/peroxidase. In contrast, only two of the strains producing a bifunctional catalase/ peroxidase (FC473 and CEP559) showed poor survival following $\mathrm{H}_{2} \mathrm{O}_{2}$ exposure. These results suggest that in most cases a bifunctional catalase/peroxidase may be associated with increased resistance to $\mathrm{H}_{2} \mathrm{O}_{2}$ exposure. The genomovar III strain CEP511 exhibited anomalous behaviour in that its percentage survival was not proportional to the amount of $\mathrm{H}_{2} \mathrm{O}_{2}$ in the assay medium. This may be related to the presence of other unstable phenotypes (colony morphology, mucoidity and pigment formation) that have been observed with this strain.

The level of resistance to $\mathrm{O}_{2}^{-}$exposure was assessed using the xanthine plus xanthine oxidase $(\mathrm{X}+\mathrm{XO})$ system and paraquat, which generate extracellular and intracellular $\mathrm{O}_{2}^{-}$, respectively. As membrane bilayers are impermeable to $\mathrm{O}_{2}^{-}$(Steinman, 1993), the results obtained with these assays may vary significantly according to the cellular localization of the SOD enzyme(s). A periplasmic SOD would provide protection against $\mathrm{X}+$ XO-generated $\mathrm{O}_{2}^{-}$while a cytoplasmic enzyme would provide protection primarily against paraquat-generated $\mathrm{O}_{2}^{-}$(De Groote et al., 1997; Wilks et al., 1998). The majority of strains analysed except for FC124 and CEP511 showed over $80 \%$ survival following exposure to the extracellular $\mathrm{O}_{2}^{-}$-generating system for $120 \mathrm{~min}$ and there were no significant differences between genomovars II, IV, $\mathrm{V}$ and VI in their response to the $\mathrm{X}+\mathrm{XO}$ challenge (Fig. 5a). Bacterial susceptibility to intracellular $\mathrm{O}_{2}^{-}$was investigated by exposing cells to increasing concentrations of paraquat ranging from 0 to $10 \mathrm{mM}$. The cells accumulate this compound and its reduction in the cytoplasm causes the formation of $\mathrm{O}_{2}^{-}$ anions. In contrast to the uniform survival patterns observed in the $\mathrm{X}+\mathrm{XO}$ system, the paraquat survival patterns showed a higher level of variability for strains belonging to all genomovars (Fig. 5b). However, statistical analysis did not reveal significant differences among the genomovars. Furthermore, the level of survival following paraquat exposure did not closely follow the pattern of SOD activity in the strains. For instance, the genomovar IV strains showed elevated levels of paraquat resistance yet their levels of SOD activity were not significantly different from those of the other strains, while the genomovar III strain, C5424, showed relatively poor paraquat resistance despite showing the highest level of SOD activity. This phenomenon possibly reflects a difference in the level of paraquat accumulated within the various strains. It has been 
$2.5 \mathrm{mM} \mathrm{H}_{2} \mathrm{O}_{2}$

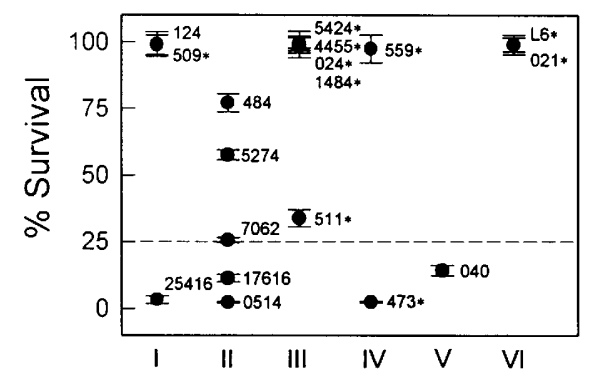

$5 \mathrm{mM} \mathrm{H}_{2} \mathrm{O}_{2}$

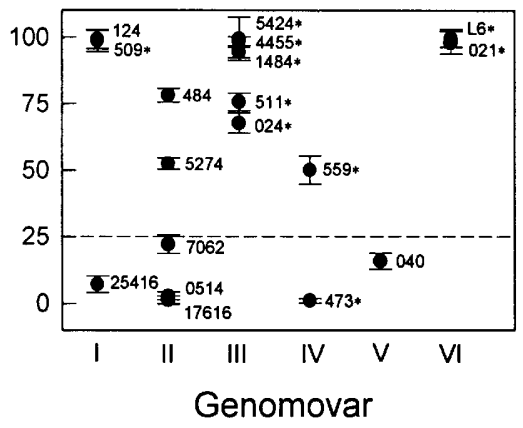

$10 \mathrm{mM} \mathrm{H}_{2} \mathrm{O}_{2}$

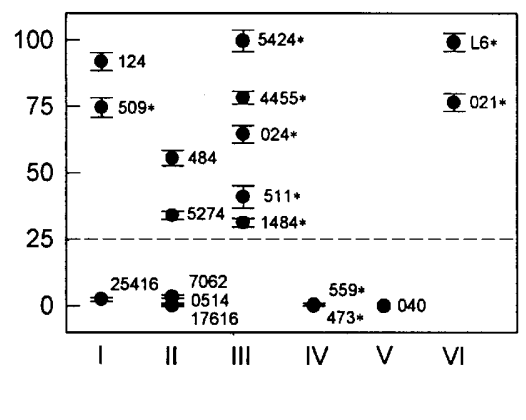

Fig. 4. Growth inhibition of $B$. cepacia complex strains exposed to $\mathrm{H}_{2} \mathrm{O}_{2}$ in vitro. Late stationary phase cells were treated with $\mathrm{H}_{2} \mathrm{O}_{2}$ at concentrations of $2.5 \mathrm{mM}, 5 \mathrm{mM}$ and $10 \mathrm{mM}$ as described in Methods. Samples were plated in triplicate for colony counts and percentage survival was calculated relative to colony counts of untreated bacteria. Bars indicate standard deviations. Individual strains are identified only by their numbers as indicated in Table 1. Asterisks indicate the strains producing bifunctional catalase/peroxidases.

(a)

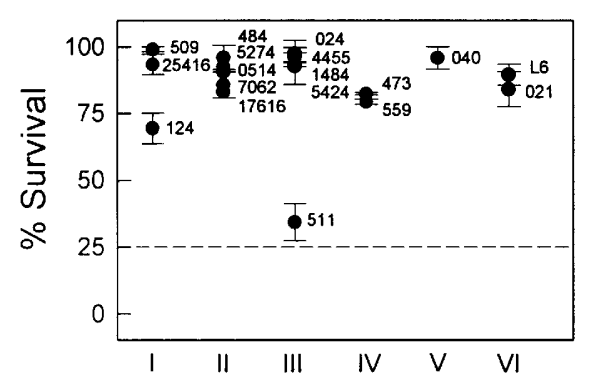

(b) $10 \mathrm{mM}$ Paraquat

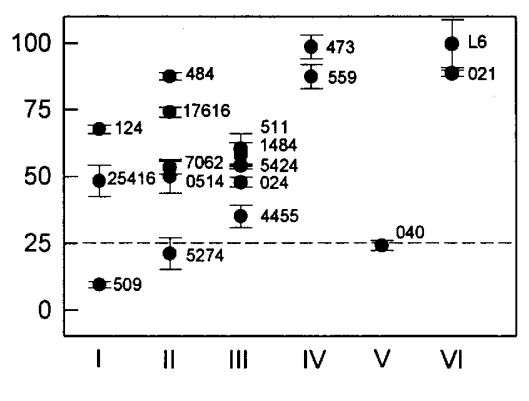

Genomovar

Fig. 5. Growth inhibition of $B$. cepacia complex strains exposed to superoxide anion. Late stationary phase cells were exposed to extracellular superoxide using the $X+X O$ superoxide generating system (a) or $10 \mathrm{mM}$ paraquat for generation of intracellular superoxide (b), as described in Methods. Samples were plated in triplicate for colony counts and percentage survival was calculated relative to colony counts of untreated bacteria. Bars indicate standard deviations. Individual strains are identified only by their numbers as indicated in Table 1.

shown that paraquat toxicity is strongly linked to the cytoplasmic concentration of the drug (Kitzler \& Fridovich, 1990). Therefore, different rates of intake and/or efflux of paraquat in the strains could account for our results.

\section{DISCUSSION}

The current study focused on the antioxidant enzymes catalase and SOD with the hypothesis that they may play a role in protecting $B$. cepacia from the oxidative killing mechanisms within the host, especially in the airways of CF patients. Strains belonging to the six established genomovars of the B. cepacia complex were investigated to identify and characterize their catalase and SOD activities. We observed the presence of 13 distinct electrophoretotypes of catalase based on their differential migration in native PAGE. As this is a nondenaturing system, the distinct migration patterns are not necessarily a consequence of differences in the molecular mass of the enzyme forms. Further analysis demonstrated that many of the slow-migrating electrophoretic forms corresponded to protein aggregates of unique fast-migrating enzymes. Therefore we propose that bands 1, 7, 8, 9, 10,11,12 and 13 represent activities associated with distinct catalase enzymes while bands 2, 4, 5 and 6 are thought to be artifacts of protein aggregation. While there appeared to be some association with genomovar assignment and the presence of specific bands, the pool of strains used in this study is not large enough to test this relationship adequately. The overall amount of catalase produced by individual strains increased as the cultures grew from exponential to stationary phase (Table 2). However, only the genomovar VI strain L6 and the genomovar II strain CEP484 showed novel catalase electrophoretotypes in stationary phase as compared to exponential phase (Table 3).

Bifunctional catalase/peroxidase enzymes were detected in all strains examined from genomovars III, IV and VI, but only in one genomovar I isolate, which also 
expressed a monofunctional catalase. These enzymes have been found to be associated with virulence in a wide range of lung pathogens such as Mycobacterium tuberculosis (Manca et al., 1999) and Legionella pneumophila (Bandyopadhyay \& Steinman 1998). Although in this study a high level of survival to $\mathrm{H}_{2} \mathrm{O}_{2}$ exposure in vitro could not be correlated with the amount of catalase activity, 7 out of the 11 strains showing the highest survival rates produced bifunctional catalase/peroxidase and belonged to genomovar I, III and VI. The prevalence of catalase/peroxidase in the genomovar III strains, which are most commonly associated with the cepacia syndrome in CF patients, and their apparent increased resistance to $\mathrm{H}_{2} \mathrm{O}_{2}$ exposure in vitro, provides justification for further study into the role of this enzyme in the pathogenesis of $B$. cepacia infections. Monofunctional catalases were found in the B. cepacia complex isolates from genomovars I, II and V. Isolates of closely related species such as Pseudomonas aeruginosa, $P$. putida, $P$. syringae and Xanthomonas possess multiple catalase isozymes (Brown et al., 1995; Katsuwon \& Anderson, 1992; Mongkolsuk et al., 1996). Under our experimental conditions, however, we have found only one enzyme class in most isolates, suggesting either that B. cepacia isolates have fewer catalase forms or, alternatively, that additional catalases may be expressed under conditions of stress not examined in this study.

Electrophoretic analysis also revealed the presence of two electrophoretotypes of SOD in B. cepacia, one of which corresponded to a larger protein aggregate. While SOD is commonly found in three major forms, Fe, $\mathrm{Mn}$ and $\mathrm{Cu} / \mathrm{Zn}$ co-factored enzymes, it is not uncommon for multiple bands of SOD to be detected (Bannister \& Calabrese, 1987). Initial attempts to classify the SOD activities using specific inhibitors yielded inconclusive results, possibly due to interference from other components found in cell-free cell lysates. As $\mathrm{H}_{2} \mathrm{O}_{2}$ is the standard inhibitor of Fe-SOD enzymes, any catalase activity present in the samples would probably limit the effectiveness of the inhibition. Therefore, following inactivation of the catalase activities we were able to identify that the SOD electrophoretotypes in B. cepacia corresponded to Fe-SODs. Using PCR amplification with degenerate primers, we have recently been able to clone a portion of the B. cepacia SOD gene that shows features of a typical Fe-SOD and that hybridized with all the strains tested (unpublished results). Gene knockout experiments in combination with studies under different growth conditions, currently under way in our laboratory, will permit us to determine whether the FeSOD is unique to B. cepacia or other SOD forms are also present in these isolates.

The level of expression of catalase and SOD was associated with the growth stage of the cultures. In all strains the activity of both enzymes increased in the cells entering stationary phase as shown by the band intensities in native gels as well as by the specific activity determinations. This may be important in vivo as it would provide a higher level of protection to those cells able to establish a chronic infection where the bacteria would find themselves under a physiological situation similar to the late stationary phase of growth. Alternatively, other conditions of stress, including tissue inflammation, may stimulate a bacterial response similar to that of stationary phase and induce a high level of expression of these enzymes. The susceptibility of $B$. cepacia to oxidative killing is suggested by the observation that neutrophils from CGD patients fail to inactivate B. cepacia (Speert et al., 1994). However, this conclusion contrasts with the apparent tolerance of $B$. cepacia to the highly oxidative environment in the CF lung, where the inflammatory response is dominated by neutrophils. Furthermore, B. cepacia strains isolated from CF patients, especially those of genomovar III, are strong catalase/peroxidase and SOD producers. One possibility to explain this paradox could be that the strains causing infections in CGD individuals are different from those found in CF patients. This may be true, at least in part, since all genomovar III isolates reported by Vandamme et al. (1997) were obtained exclusively from CF patients. In addition, the unique nature of the CF lung and airways may also contribute to the possible escape of $B$. cepacia from oxidative killing. Studies into the pathology of bacterial infections in the respiratory airways of CF patients have identified chronic inflammation as a major cause of tissue damage and loss of gas-exchange function (Tager et al., 1998). Recruitment of neutrophils to the site of infection is associated with a release of reactive oxygen species and other toxic compounds. Ongoing release of reactive oxygen species may in turn overwhelm the cellular antioxidant defences and lead to the accumulation of toxic levels of these compounds, which may damage the lung cells (Bals et al., 1999; Suttorp \& Simon, 1982). Lipopolysaccharide (LPS) has been shown to elicit a powerful inflammatory response in neutrophils (Forehand et al., 1993; Worthen et al., 1988). Interestingly, it has been shown that the LPS of B. cepacia elicits a much greater inflammatory response as measured by $\mathrm{O}_{2}^{-}$release than the LPS of $P$. aeruginosa, another common CF pathogen (Hughes et al., 1997; Zughaier et al., 1999). These observations are consistent with our own findings indicating that activation of macrophages following phagocytosis of B. cepacia is primarily due to LPS release (Saini et al., 1999). Therefore, it is possible that bacterial antioxidant defences allow B. cepacia to survive and persist despite the oxidative stress in the lung promoted by LPS-mediated stimulation of inflammatory cells. Experimental evidence showing that $B$. cepacia strains can survive within macrophages in the presence of macrophage cell activation supports these conclusions (Saini et al., 1999). The resistance of $B$. cepacia strains to toxicity by reactive oxygen species in lung tissue, in association with the ability of these isolates to survive intracellularly (Burns et al., 1996; Marolda et al., 1999; Martin \& Mohr, 2000; Saini et al., 1999) may explain, at least in part, their persistence as well as their ability to continually elicit an inflammatory response. Furthermore, a recent study showed that nitric oxide acts synergistically with reactive oxygen species to 
kill B. cepacia in vitro (Smith et al., 1999) and suggested that persistence of B. cepacia in CF patients may be associated with a defect in the inducible nitric oxide synthase activity in these patients (Kelley \& Drumm, 1998). Taken together, these factors would explain the high level of tissue damage and lethality commonly associated with $B$. cepacia infection in CF patients, especially with genomovar III isolates. Confirmation of this pathogenic model awaits further experiments using animal models of lung infection as well as the generation of genetically defined catalase- and SOD-deficient mutants.

\section{ACKNOWLEDGEMENTS}

We thank D. Robinson, E. Mahenthiralingam, D. Henry and D. P. Speert, Research Institute for Children's and Women's Health, Vancouver, British Columbia, Canada, T. Lessie, Massachusetts Institute of Technology, and H. Schellhorn, McMaster's University, for providing strains used in this study, and D. E. Heinrichs for a critical review of the manuscript. Statistical analysis was performed by G. Y. Zou, Department of Epidemiology and Biostatistics, University of Western Ontario. M.D.L. was supported by a fellowship from the National Science and Engineering Research Council of Canada. This work was supported by operating grants from the Canadian Cystic Fibrosis Foundation and the Medical Research Council of Canada.

\section{REFERENCES}

Bals, R., Weiner, D. J. \& Wilson, J. M. (1999). The innate immune system in cystic fibrosis lung disease. J Clin Invest 103, 303-307. Bandyopadhyay, P. \& Steinman, H. M. (1998). Legionella pneumophila catalase-peroxidases: cloning of the katB gene and studies of KatB function. J Bacteriol 180, 5369-5374.

Bannister, J. V. \& Calabrese, L. (1987). Assays for superoxide dismutase. Methods Biochem Anal 32, 279-312.

Barnes, A. C., Horne, M. T. \& Ellis, A. E. (1996). Effect of iron on expression of superoxide dismutase by Aeromonas salmonicida and associated resistance to superoxide anion. FEMS Microbiol Lett 142, 19-26.

Barnes, A. C., Balebona, M. C., Horne, M. T. \& Ellis, A. E. (1999). Superoxide dismutase and catalase in Photobacterium damselae subsp. piscidia and their roles in resistance to reactive oxygen species. Microbiology 145, 483-494.

Beauchamp, C. \& Fridovich, I. (1971). Superoxide dismutase: improved assays and an assay applicable to acrylamide gels. Anal Biochem 44, 276-287.

Brown, S. M., Howell, M. L., Vasil, M. L., Anderson, A. J. \& Hassett, D. J. (1995). Cloning and characterization of the katB gene of Pseudomonas aeruginosa encoding a hydrogen peroxideinducible catalase: purification of KatB, cellular localization, and demonstration that it is essential for optimal resistance to hydrogen peroxide. J Bacteriol 177, 6536-6544.

Burkholder, W. H. (1950). Sour skin, a bacterial rot of onion bulbs. Phytopathology 40, 115-117.

Burns, J. L., Jonas, M., Chi, E. Y., Clark, D. K., Berger, A. \& Griffith, A. (1996). Invasion of respiratory epithelial cells by Burkholderia (Pseudomonas) cepacia. Infect Immun 64, 4054-4059.

Carlioz, A. \& Touati, D. (1986). Isolation of superoxide dismutase mutants in Escherichia coli: is superoxide dismutase necessary for aerobic life? EMBO J 5, 623-630.
Cline, M. J. (1975). Chemotaxis, phagocytosis and microbial killing. In The White Cell, pp. 71-82. Edited by M. J. Cline. Cambridge, MA: Harvard University Press.

De Groote, M. A., Ochsner, U. A., Shiloh, M. U. \& 7 other authors (1997). Periplasmic superoxide dismutase protects Salmonella from products of phagocyte NADPH-oxidase and nitric oxide synthase. Proc Natl Acad Sci US A 94, 13997-14001.

Fang, F. C., DeGroote, M. A., Foster, J. H. \& 8 other authors (1999). Virulent Salmonella typhimurium has two periplasmic $\mathrm{Cu}, \mathrm{Zn}$-superoxide dismutases. Proc Natl Acad Sci USA 96, 7502-7507.

Forehand, J. R., Johnston, R. B. J. \& Bomalaski, J. S. (1993). Phospholipase A2 activity in human neutrophils. Stimulation by lipopolysaccharide and possible involvement in priming for an enhanced respiratory burst. J Immunol 151, 4918-4925.

Franzon, V. L., Arondel, I. \& Sansonetti, P. I. (1990). Contribution of superoxide dismutase and catalase activities to Shigella flexneri pathogenesis. Infect Immun 58, 529-535.

Fridovich, I. (1978). The biology of oxygen radicals. Science 201, 875-879.

Gillis, M., Van, T. V., Bardin, R. \& 7 other authors (1995). Polyphasic taxonomy in the genus Burkholderia leading to an emended description of the genus and proposition of Burkholderia vietnamiensis sp. nov. for $\mathrm{N}_{2}$-fixing isolates from rice in Vietnam. Int J Syst Bacteriol 45, 274-289.

Govan, J. R. W. \& Deretic, V. (1996). Microbial pathogenesis in cystic fibrosis: mucoid Pseudomonas aeruginosa and Burkholderia cepacia. Microbiol Rev 60, 539-574.

Govan, J. R. W. \& Vandamme, P. (1998). Agricultural and medical microbiology: a time for bridging gaps. Microbiology 144, 2373-2375.

Govan, J. R., Hughes, J. E. \& Vandamme, P. (1996). Burkholderia cepacia: medical, taxonomic and ecological issues. J Med Microbiol 45, 395-407.

Heikkila, R. E. \& Cabbat, F. (1976). A sensitive assay for superoxide dismutase based on the autoxidation of 6-hydroxydopamine. Anal Biochem 75, 356-362.

Hughes, J. E., Stewart, J., Barclay, G. R. \& Govan, J. R. (1997). Priming of neutrophil respiratory burst activity by lipopolysaccharide from Burkholderia cepacia. Infect Immun 65, 4281-4287.

Imlay, J. A. \& Linn, S. (1988). DNA damage and oxygen radical toxicity. Science 240, 1302-1309.

Katsuwon, J. \& Anderson, A. J. (1989). Response of plantcolonizing pseudomonads to hydrogen peroxide. Appl Environ Microbiol 55, 2985-2989.

Katsuwon, J. \& Anderson, A. J. (1992). Characterization of catalase activities in a root-colonizing isolate of Pseudomonas putida. Can J Microbiol 38, 1026-1032.

Kelley, T. G. \& Drumm, M. L. (1998). Inducible nitric oxide synthase expression is reduced in cystic fibrosis murine and human airway epithelial cells. J Clin Invest 102, 1200-1207.

Kitzler, J. W., Minakami, H. \& Fridovich, I. (1990). Effects of Paraquat on Escherichia coli: differences between B and K-12 strains. J Bacteriol 172, 686-690.

Koch, C. \& Hoiby, N. (1993). Pathogenesis of cystic fibrosis. Lancet 341, 1065-1069.

LiPuma, J. J., Dasen, S. E., Nielson, D. W., Stern, R. C. \& Stull, T. L. (1990). Person-to-person transmission of Pseudomonas cepacia between patients with cystic fibrosis. Lancet 336, 1094-1096. 
Loewen, P. C. \& Triggs, B. L. (1984). Genetic mapping of katF, a locus that with $k a t E$ affects the synthesis of a second catalase species in Escherichia coli. J Bacteriol 160, 668-675.

Mahenthiralingam, E., Campbell, M. E., Henry, D. A. \& Speert, D. (1996). Epidemiology of Burkholderia cepacia infection in patients with cystic fibrosis: analysis by randomly amplified polymorphic DNA fingerprinting. J Clin Microbiol 34, 2914-2930.

Manca, C., Paul, S., Barry, C. L. I., Freedman, V. H. \& Kaplan, G. (1999). Mycobacterium tuberculosis catalase and peroxidase activities and resistance to oxidative killing in human monocytes in vitro. Infect Immun 67, 74-79.

Mandell, G. L. (1975). Catalase, superoxide dismutase, and virulence of Staphylococcus aureus. In vitro and in vivo studies with emphasis on staphylococcal-leukocyte interaction. J Clin Invest 55, 561-566.

Marcinkeviciene, J. A., Magliozzo, R. S. \& Blanchard, J. S. (1995). Purification and characterization of the Mycobacterium smegmatis catalase-peroxidase involved in isoniazid activation. $\mathrm{J} \mathrm{Biol}$ Chem 270, 22290-22295.

Marolda, C. L., Hauröder, B., John, M. A., Michel, R. \& Valvano, M. A. (1999). Intracellular survival and saprophytic growth of isolates from the Burkholderia cepacia complex in free-living amoebae. Microbiology 145, 1509-1517.

Martin, D. W. \& Mohr, C. D. (2000). Invasion and intracellular survival of Burkholderia cepacia. Infect Immun 68, 24-29.

Membrillo-Hernandez, J., Coopamah, M. D., Anjum, M. F., Stevanin, T. M., Kelly, A., Hughes, M. N. \& Poole, R. K. (1999). The flavohemoglobin of Escherichia coli confers resistance to a nitrosating agent, a nitric oxide releaser, and paraquat and is essential for transcriptional responses to oxidative stress. $J$ Biol Chem 274, 748-754.

Mongkolsuk, S., Loprasert, S., Vattanaviboon, P., Chanvanichayachai, C., Chamnongpol, S. \& Supsamran, N. (1996). Heterologous growth phase- and temperature-dependent expression and $\mathrm{H}_{2} \mathrm{O}_{2}$ toxicity protection of a superoxide-inducible monofunctional catalase gene from Xanthomonas oryzae pv. oryzae. J Bacteriol 178, 3578-3584.

Odell, E. W. \& Segal, A. W. (1991). Killing of pathogens associated with chronic granulomatous disease by the non-oxidative microbicidal mechanisms of human neutrophils. J Med Microbiol 34, 129-135.

Palleroni, N. J. (1992). Human and animal pathogenic pseudomonads. In The Prokaryotes: a Handbook on the Biology of Bacteria; Ecophysiology, Isolation, Identification, Applications, pp. 3086-3103. Edited by A. Balows, H. G. Trüper, M. Dworkin, W. Harder \& K. H. Schleifer. New York: Springer.

Saini, L., Galsworthy, S., John, M. \& Valvano, M. A. (1999). Intracellular survival of isolates from the Burkholderia cepacia complex in a murine macrophage cell line. Microbiology 145, 3465-3475.

Schnell, S. \& Steinman, H. M. (1995). Function and stationaryphase induction of periplasmic copper-zinc superoxide dismutase and catalase/peroxidase in Caulobacter crescentus. J Bacteriol 177, 5924-5929.

Smith, A. W., Green, J., Eden, C. E. \& Watson, M. L. (1999). Nitric oxide-induced potentiation of the killing of Burkholderia cepacia by reactive oxygen species: implications for cystic fibrosis. J Med Microbiol 48, 419-423.

Speert, D. P., Bond, M., Woodman, R. C. \& Curnutte, J. T. (1994).
Infection with Pseudomonas cepacia in chronic granulomatous disease: role of non-oxidative killing by neutrophils in host defense. J Infect Dis 170, 1524-1531.

Steinman, H. M. (1993). Function of periplasmic copper-zinc superoxide dismutase in Caulobacter crescentus. J Bacteriol 175, 1198-1202.

Suttorp, N. \& Simon, L. M. (1982). Lung cell oxidant injury. Enhancement of polymorphonuclear leukocyte-mediated cytotoxicity in lung cells exposed to sustained in vitro hyperoxia. $J$ Clin Invest 70, 342-350.

Tablan, O. C., Chroba, T. L., Schidlow, D. V. \& 7 other authors (1985). Pseudomonas cepacia colonization in patients with cystic fibrosis : risk factors and clinical outcome. J Pediatr 107, 382-387.

Tager, A. M., Wu, J. \& Vermeulen, M. W. (1998). The effect of chloride concentration on human neutrophil functions: potential relevance to cystic fibrosis. Am J Respir Cell Mol Biol 19, 642-652.

Tsolis, R. M., Baumler, A. J. \& Heffron, F. (1995). Role of Salmonella typhimurium Mn-superoxide dismutase (SodA) in protection against early killing by $\mathrm{J} 774$ macrophages. Infect Immun 63, 1739-1744.

Vandamme, P., Holmes, B., Vancanneyt, M. \& 8 other authors (1997). Occurrence of multiple genomovars of Burkholderia cepacia in cystic fibrosis patients and proposal of Burkholderia multivorans sp. nov. Int J Syst Bacteriol 47, 1188-1200.

Vandamme, P., Mahenthiralingam, E., Holmes, B., Coyene, T., Hoste, B., De Vos, P., Henry, D. \& Speert, D. P. (2000). Identification and population structure of Burkholderia stabilis sp. nov. (formerly Burkholderia cepacia Genomovar IV). J Clin Microbiol 38, 1042-1047.

Wayne, L. G. \& Diaz, G. A. (1986). A double staining method for differentiating between two classes of mycobacterial catalase in polyacrylamide electrophoresis gels. Anal Biochem 157, 89-92.

Weisiger, R. A. \& Fridovich, I. (1973). Superoxide dismutase: organelle specificity. J Biol Chem 248, 3582-3592.

Welch, D. F., Sword, C. P., Brehm, S. \& Dusanic, D. (1979). Relationship between superoxide dismutase and pathogenic mechanisms of Listeria monocytogenes. Infect Immun 23, 863-872.

Wilks, K. E., Dunn, K. L. R., Farrant, J. L., Reddin, K. M., Gorringe, A. R., Langford, P. R. \& Kroll, J. S. (1998). Periplasmic superoxide dismutase in meningococcal pathogenicity. Infect Immun 66, 213-217.

Worthen, G. S., Seccombe, J. F., Clay, K. L., Guthrie, L. A. \& Johnston, R. B. J. (1988). The priming of neutrophils by lipopolysaccharide for production of intracellular platelet-activating factor. Potential role in mediation of enhanced superoxide secretion. J Immunol 140, 3553-3559.

Xiu, Q. \& Pan, S. Q. (2000). An Agrobacterium catalase is a virulence factor involved in tumourigenesis. Mol Microbiol 35, 407-414.

Zughaier, S. M., Ryley, H. C. \& Jackson, S. K. (1999). Lipopolysaccharide (LPS) from Burkholderia cepacia is more active than LPS from Pseudomonas aeruginosa and Stenotrophomonas maltophilia in stimulating tumour necrosis factor alpha from human monocytes. Infect Immun 67, 1505-1507.

Received 3 April 2000; revised 10 July 2000; accepted 28 September 2000. 